Research Report No. 21/2008

\title{
The Province of Jurisprudence (Really) Redetermined
}

Allan Hutchinson

Osgoode Hall Law School of York University, ahutchinson@osgoode.yorku.ca

Follow this and additional works at: http:/ / digitalcommons.osgoode.yorku.ca/clpe

\section{Recommended Citation}

Hutchinson, Allan, "The Province of Jurisprudence (Really) Redetermined" (2008). Comparative Research in Law E Political Economy. Research Paper No. 21/2008.

http://digitalcommons.osgoode.yorku.ca/clpe/194 


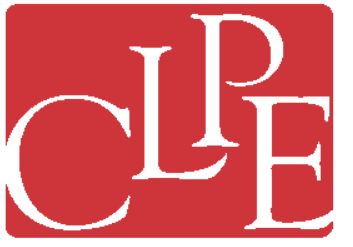

\section{Comparative Research in Law \& Political Economy}

CLPE RESEARCH PAPER 21/ 2008

Allan C. Hutchinson

The Province of J urisprudence (Really) Redetermined

To be published in J ulius Stone: A Study of Influence (Helen Irving and Kevin Walton, eds., 2008)

EDTORS: Peer Zumbansen (Osgoode Hall Law School, Toronto, Director, Comparative Research in Law and Political Economy, York University), J ohn W. Cioffi (University of California at Riverside), Lindsay Krauss (Osgoode Hall Law School, Toronto, Production Editor) 

CLPE Research Paper 21/2008

Vol. 04 No. 04 (2008)

\title{
Allan C. Hutchinson \\ THE PROVInCE OF JURISPRUdENCE (REALLY) REDETERMINED
}

\begin{abstract}
When Julius Stone published his famous essay, The Province of Jurisprudence Redetermined, in 1944, he had reasonable cause for genuine optimism. English jurisprudence had been in the doldrums since the initial flurry of activity and excitement following Austin's launch of the modern project of analytical jurisprudence in 1832 with his The Province of Jurisprudence Determined. Most of the subsequent scholarship had simply refined and riffed unimaginatively on the basic Austinian themes. Yet, as the Second World War came to a close, there were signs that the time was ripe for a different and more vibrant approach to jurisprudential study. Julius Stone was at the forefront of such a spirited revival. Unfortunately, history has not been kind to Stone's optimistic obituary for analytical jurisprudence. Within a decade of his famous essay's publication, Hart's revival of legal positivism had restored the flagging fortunes of analytical jurisprudence. More sociologically-based efforts to expand the province of jurisprudence continued to be treated as marginal and secondary. This is an unfortunate state of affairs. Accordingly, in this essay, I want to do three things -- to chronicle the hold that analytical jurisprudence still exerts as the 'default theory' of much legal thought and practice; to explore how Stone may have unintentionally contributed to that state of affairs; and to suggest how that continuing influence can be arrested and perhaps reversed. I intend to push through on an unconditional critique of analytical jurisprudence and to recommend an alternative approach that derives its rationale and motivation from a robust commitment to what I will term 'strong democracy'.
\end{abstract}

Keywords: Julius Stone, analytical jurisprudence, strong democracy

JEL classification: K10, K33 
Author Contact:

Allan C. Hutchinson

Osgoode Hall Law School, York University

4700 Keele St. Toronto Ontario, M3J 1P3

Email: ahutchinson@osgoode.yorku.ca 


\title{
The Provice of Jurisprudence (REAlly) REDETERMINED
}

\author{
Allan C. Hutchinson ${ }^{*}$
}

\section{INTRODUCTION}

\section{A. HEADING 2}

\section{HEADING 3}

"Insofar as the theory of justice has been taught at all it has been presented as a body of ideas beyond the proper scrutiny of the discreet lawyer, rather than as a necessary part of his equipment."

-- Julius Stone

When Julius Stone published his famous essay, The Province of Jurisprudence Redetermined, in 1944, he had reasonable cause for genuine optimism. English jurisprudence had been in the doldrums since the initial flurry of activity and excitement following Austin's launch of the modern project of analytical jurisprudence in 1832 with his The Province of Jurisprudence Determined. Most of the subsequent scholarship had simply refined and riffed unimaginatively on the basic Austinian themes. Yet, as the Second World War came to a close, there were signs that the time was ripe for a different and more vibrant approach to jurisprudential

\footnotetext{
* Distinguished Research Professor, Osgoode Hall Law School, York University, Toronto. I am grateful to Paul Hughes, Brian Tamanaha, Rachael Walsh, and Joel ColonRios for their critical comments and helpful suggestions. This essay draws upon material to be published as part of THE PROVINCE OF JURISPRUDENCE DEMOCRATISED by Oxford University Press.
} 
study. Stone was at the forefront of such a spirited revival. Fresh from an invigorating stretch in the United States during the 1930s where he was inspired by the Realist writings generally and those of his mentor, Roscoe Pound, in particular, Stone was imbued with a broader sense of jurisprudence's possibilities for understanding law as a social process. Consequently, after a reign of over a century, Stone seemed justified in concluding that the long-standing dominion of analytical jurisprudence was finally coming to a warranted end.

Unfortunately, history has not been kind to Stone's optimistic obituary for analytical jurisprudence. Within a decade of his famous essay's publication, Hart's revival of legal positivism had restored the flagging fortunes of analytical jurisprudence. More sociologically-based efforts to expand the province of jurisprudence continued to be treated as marginal and secondary. Indeed, although there has been some progress in the last few years, analytical jurisprudence remains the default legal theory of the academe and, insofar as it is cognizant of such matters, the practising bar. This is an unfortunate state of affairs. Accordingly, in this essay, I want to do three things -- to chronicle the hold that analytical jurisprudence still exerts as the 'default theory' of much legal thought and practice; to explore how Stone may have unintentionally contributed to that state of affairs; and to suggest how that continuing influence can be arrested and perhaps reversed. I intend to push through on an unconditional critique of analytical jurisprudence and to recommend an alternative approach that derives its rationale and motivation from a robust commitment to what I will term 'strong democracy'.

\section{ANALYTICAL JURISPRUDENCE RULES}

Efforts to understand law's general workings and character have been legion. From Plato and before, the attempt to appreciate the role of law in society has been a standard feature of academic texts and popular commentary. ${ }^{1}$ However, until the beginning of the Nineteenth Century,

1 See, for example, EDWIN PATTERSON, JURISPRUDENCE: MEN AND IDEAS OF THE LAW (1953). 
these inquiries were very much part of a larger literature on justice and government; there was scant attention paid to the more rarified task of understanding law in and on its own terms. However, in 1932, John Austin set about changing that situation. With his The Province of Jurisprudence Determined and its central ambition to develop "the science of jurisprudence (or, simply and briefly, jurisprudence)"2 , he decreed that 'what is law?' was the question to be answered by legal theorists and secondly that philosophical analysis was the way to go about answering it. While Austin's own exertions to provide a convincing answer were unsuccessful and of no lasting significance, his pioneering efforts to delineate the intellectual territory on which these endeavours took place and to suggest legitimate ways to perform them has become the official modus operandi of jurists. The basic thrust of analytical jurisprudence is the sustained effort to provide an understanding of 'law' which is both universal (i.e., it transcends any particular or local practices) and general (i.e., it encompasses and informs all other inquiries into law). Although other disciplinary approaches enjoy periodic favour in legal academe, they are treated as distinctly supplemental. Analytical jurisprudence has become jurisprudence tout court.

For over a century after Austin's The Province launched the central project of analytical jurisprudence, his ideas remained dominant and were uncritically followed by several generations of jurists. However, by the 1940s, it seemed to be generally conceded that, whatever its former significance and intellectual pre-eminence, analytical jurisprudence was on the ropes, if not actually out for the count. For instance, in 1941, John Dewey had opined that positivism "already wears a certain antiquarian air, so that it is hard even in the imagination to see why once it had such vogue."3 So by 1944, when Julius Stone published his famous essay, The Province of Jurisprudence Redetermined, he had reasonable cause for genuine optimism in committing "an act of revolt” against Austinian

2 JOHN AUSTIN, THE PROVINCE OF JURISPRUDENCE DETERMINED 126 (1832: H.L.A. Hart ed. 1955).

3 John Dewey, My Philosophy of Law in MY PHILOSOPHY OF LAW 81 (1941). For similar assessments, see Ivor Jennings, A Plea for Utilitarianism, 2 MOD. L. REV. 22 (1938). 
tradition. $^{4}$ Yet, only a few years later, a revival of an Austin-based analytical jurisprudence had begun in earnest. This was largely down to the singular efforts of Herbert Hart who had been appointed to the Oxford Chair of Jurisprudence in 1952. Almost single-handedly, he undertook a bracing and critical revitalization of the analytical tradition; it was Hart's dubious destiny to dispel the musty fug around The Province and to bring analytical jurisprudence, especially in its positivist incarnation, squarely and decidedly back in vogue. Although he completely rejected Austin's 'command theory' of law, Hart did so in order to fulfil better Austin's broader analytical ambitions and to locate "the key to the science of jurisprudence." 5

Nevertheless, despite its undoubted dominance in the second half of the Twentieth Century, analytical jurisprudence is now considered to have had its day. Indeed, there is much to be said for the standard and increasing chorus of contemporary disapproval -- "flat and repetitive", "socially unaware but philosophically obsessed”, “repetitions, trivial, and almost entirely pointless", and "almost scholastic" -- about analytical jurisprudence. However, any assessment that an Austin-inspired analytical jurisprudence is on its last legs is hasty and merely wishful

4 Julius Stone, The Province of Jurisprudence Redetermined, 7 MOD. L. REV. 97 (1944).

5 Hart, supra, note 10 at 81. Although The Concept of Law is feted as a monumental contribution to legal philosophy, Hart originally wrote it "with English undergraduate readers in mind.” Id. at 238.

6 Jeremy Waldron, Legal and Political Philosophy in THE OXFORD HANDBOOK OF JURISPRUDENCE AND PHILOSOPHY OF LAW 381 (2002); Frederick Schauer, Positivism Through Thick and Thin in ANALYZING LAW; NEW ESSAYS IN LEGAL THEORY 69 (Brian Bix ed. 1998); William Twining, Imagining Bentham: A Celebration in CURRENT LEGAL PROBLEMS 1998: LEGAL THEORY AT THE END OF THE MILLENNIUM 21 (M.D.A. Freeman ed. 1998); and James Allen, A Modest Proposal, 23 OXF. J. of LEG. STUD. 197 at 209 (2003). See also David Dyzenhaus, Positivism's Stagnant Research Programme, 20 OXF. J. of LEG. STUD. 703 at 719 (2000); Dennis Patterson, Notes on the Methodology Debate in Contemporary Jurisprudence: Why Sociologists Might be Interested, 8 LAW \& SOCIOLOGY 254 at 258 (Michael Freeman ed. 2005); and Brian Tamanaha, The Contemporary Relevance of Legal Positivism, 32 AUST. J. OF LEGAL PHIL. 1 (2007). 
thinking. If the amount of material published in analytical jurisprudence and about it is any indicator, it is very much alive and kicking. Also, the quantity of output is reasonably matched by its high quality. Some of the leading academics of their generation are part of the analytical tradition; Joseph Raz, Ronald Dworkin, and Jules Coleman stand in the first rank of legal scholarship by any lights. Although the United Kingdom remains its traditional seat, many analytical jurists reside and write in the United States: Fred Schauer, Stephen Perry, Jeremy Waldron and others cannot be dismissed as mere bit-players. ${ }^{7}$ While the leading figures of analytical jurisprudence are predominantly male, there are a few important female contributors, such as Nicola Lacey and Julie Dickson, to this tradition. Notwithstanding its continuing publishing presence, critics still contend that analytical jurisprudence has lost any genuine relevance and influence for the performance of modern legal scholarship and study at large. While this is a tempting assessment, it is mistaken.

Analytical jurisprudence is still very much an intellectual force to be reckoned with not only in legal academe, but also for bench and bar. In direct opposition to the claims of its would-be undertakers, analytical jurisprudence can be treated as the default theory of the legal world; its influence is so common and so ingrained that it has become almost pervasive and unappreciated. While there is no deep and monolithic causal link between analytical jurisprudence and all contemporary lawjobs, there is a strong connection and, at least, a plausible complementarity between analytical jurisprudence and the formalist/doctrinal tradition of legal scholarship. Indeed, the available data strongly suggests that, while there has been a definite increase in the amount and range of 'law and' scholarship, there is no convincing sense in which "law journal articles became significantly less doctrinal in the period between 1982 and 1996": the resort to a variety of instrumental and empirical approaches has tended to operate "as methods to enrich the analysis of doctrine, not as substitutes

7 The empirical literature is weak and offers little serious help. Available data tends to be jurisdiction-specific and subject-specific. See Fred R. Shapiro, The Most-Cited Legal Books Published Since 1978, 29 J. LEGAL STUD. 397 (2000) and Brian Leiter’s Law School Reports at http://leiterlawschool.typepad.com/. Ironically, analytical jurisprudence fares best and tends to dominate in the category 'British Legal Books Most Cited in Social Sciences Citation Index' with five (Herbert Hart, John Finnis, Neil MacCormick and Joseph Raz twice) in the top Ten. Shapiro, id. 
for it.” Insofar as analytical jurisprudence gives priority to theoretical argumentation, sound evidence, avoidance of ambiguity, conceptual clarity, systemic coherence, and ahistorical orientation, doctrinal scholarship aspires to adopt similar tools and techniques: it takes a set of accepted legal materials and sources, extracts from them their underlying patterns and essential structures, and re-organizes those materials in line with a more coherent and compelling account of the issue to be analysed. Of course, while such conceptual work is often supplemented and reinforced by reference to some favoured set of instrumental, empirical or teleological criteria, such reference is selective: it is the non-analytical exception that proves the analytical rule. Moreover, this style and approach remains the stock-in-trade of most law reviews and periodicals.

Similar claims can also be made about legal education, adjudication and legal practice generally. Apart from legal theory courses (which still orient themselves around analytical debates), the analytical/conceptual approach still dominates in the classroom. Teachers, often indifferent to subject-matter, present the basic resources and materials of the law in their most coherent and organised manner: criticism is largely reserved for pointing out inconsistencies, discrepancies, incongruities, etc. For instance, an examination of standard and popular casebooks reveals that the core mission is to select the basic legal sources and doctrinal materials, to pose a series of questions about how one case or principle relates to another, and to thereby illuminate the formal categories and structures which underpin the law. Again, of course, many teachers bring to their classes a variety of different perspectives (e.g., economic, historical, social, moral, etc.), but they are used to counterbalance and, only occasionally, subvert or supplement this pre-dominantly internalised analysis. The often unstated premise that law students soon seize upon is that it is their ability to learn the formal tools of legal analysis (rather the extant details of legal doctrine) and then apply them to extant legal materials that will be most prized. ${ }^{9}$

8 Robert Ellickson, Trends in Legal Scholarship: A Statistical Study, 29 J. LEGAL STUD. 517 at 523 and 524 (2000).

9 See, for example, W. FARNSWORTH, THE LEGAL ANALYSTS: A TOOLKIT FOR THINKING ABOUT THE LAW (2007). 
Judges pay little direct attention to the work of jurisprudential scholars: reference to basic texts and writings tend to be selective and sporadic at best. Also, their reference to academic commentary generally, even in its more doctrinal mode, is limited and unsystematic; the tendency is to utilise it as persuasive rather than authoritative sources. When they do cite such material, they are critical of it for its failure to be more useful to the performance of their immediate responsibilities in determining cases. Nevertheless, in mounting such critiques against modern scholarly literature, they do tend to give a back-handed approval to a depiction of adjudication that meshes quite easily with the mood of analytical jurisprudence. For instance, one senior Canadian judge has noted that "academic commentary that is useful to judges is that which assembles and rationalizes judicial decisions in a given field of law ... [and] draws out the general principles that these decisions imply."10 It is not surprising that judicial practice should be reasonably in line with the underlying theoretical framework of both legal scholarship and legal education. Within the confines of democratic constitutionalism and separation of powers, judges maintain that their basic commitment and responsibility is to identify the law, develop it in a consistent and principled fashion, and apply to the facts at hand. Of course, judges embrace the idea that 'justice' is an integral component of any sound and defensible adjudicative practice, but they maintain that such a challenge can be best met by 'following the rules laid down' as much as by fashioning or tailoring new rules from whole cloth. In line with the general orientation of analytical jurisprudence, the self-image of the rank-and-file judge is that of a technician and bureaucrat as much as policy-maker. The discourse of precedents, appropriate sources, binding authority, principled consistency and the like is very much the working language of the judges. Of course, there are examples of cases and opinions where the analytical temper gives way to a more substantive imperative, but these are again exceptional instances that point up the more usual and precedent-following approach

10 Michel Bastarache, The Role of Academics and Legal Theory in Judicial Decision-Making, 37 ALTA L. REV. 739 at 740 (1999). See also Harry Edwards, The Growing Disjunction Between Legal Education and the Legal Profession, 91 MICH . L. REV. 34 (1992). 
that explains the greater balance of adjudicative practice. ${ }^{11}$

Again, although most practising lawyers give little thought or even respect to jurisprudential writings, the traditional underpinnings of legal practice depend on a definite theoretical model of what lawyers should do if they wish to act with legal and professional responsibility. Moreover, the regnant model is closely allied to analytical positivism both theoretically and historically. This manifests itself in two different ways. First, the traditional image of lawyering is centred on the idea that lawyers are super-technocrats; they possess a special set of talents and techniques which they deploy for the advantage of the people who hire them. Lawyers are encouraged to be neutral on the substantive content and thrust of the law; their task is very much to apply the law, a little to criticize it, but most certainly not to make it. Their commitment is to the legal system which, even when they are working around and within it, must be accepted as given. While they are permitted some misgivings about the merit of particular laws or decisions, these are to be treated as mistakes or deviations from the correct path of the law. Their faith in the system's overall correctness is what underpins their support for the basic Rule of Law and its values. From an analytical standpoint, they subscribe to the general separation of law and morality as well emphasising the importance of source over substance. Secondly, lawyers must almost be indifferent to the identity of their clients and the moral rectitude of their interests. Lawyers' primary obligation is to their clients and it is these interests which must be put ahead of all others. Echoing a strongly positivist commitment, one proponent of the traditional approach states that "a lawyer is morally entitled to act in this formal, representative way even if the result is an injustice, because the legal system which authorises both the injustice ... and the formal gesture for working it insulates him from personal moral responsibility."12

11 This is not to suggest that judges always (or perhaps ever) do what they say that they do. See A. HUTCHINSON, IT'S ALL IN THE GAME: A NONFOUNDATIONALIST ACCOUNT OF LAW AND ADJUDICATION (2000). Also, the connection between analytical jurisprudence and legal formalism is far from straightforward or established.

12 Charles Fried, The Lawyer as Friend: The Moral Foundations of the LawyerClient Relation, 85 YALE L.J. 1060 at 1084 (1976). For a critique of this, see A. 
Consequently, although Austin and The Province's influence is more indirect than direct, analytical jurisprudence remains highly significant to the worlds of legal theory, legal scholarship and even legal education. Lawyers remain in relative thrall to its intimations and admonitions. However, while this might offer some reassurance to analytical jurists, it ought not to suggest that its pervasive, if unappreciated influence is testament to its validity or merit. Its ubiquitous and longstanding presence cannot underwrite its contested theoretical status. While the jurisprudential rejection of analytical jurisprudence will not necessarily end its influence on legal scholarship and legal education, it will demand that there be a different and better defence of its customary dominance or, at least, that the political basis of its enduring appeal will be more widely appreciated. It was to Stone's eternal credit that he launched a full-blown assault on analytical jurisprudence and sought to offer a compelling alternative. However, in characteristic, but misplaced gesture of generosity, he made unnecessary concessions to the analytical approach to jurisprudential study that enabled it to maintain an undeserved intellectual legitimacy. It is to Stone's critique that I now turn.

\section{STONE’S REVOLT}

In jurisprudence, as with comedy, timing is everything. The years that Julius Stone spent in the United States from 1931 to 1936 at Harvard Law School had a massive impact on him throughout his academic career. This was the heyday of American Legal Realism. Under the mentorship of Harvard's Dean, the monumental Roscoe Pound, Stone breathed in the rich intellectual air of this anti-formalist tendency and warmed to its iconoclastic attitude. So invigorated, he determined to begin his own jurisprudential work as "an act of revolt" against the stifling influence of the Austinian tradition of analytical jurisprudence which still held sway in the rest of the English-speaking world. ${ }^{13}$ Although this commitment was

HUTCHINSON, LEGAL ETHICS AND PROFESSIONAL RESPONSIBILITY ch.3 $\left(2^{\text {nd }}\right.$ ed. 2006).

13 Stone, The Province of Jurisprudence Redetermined, 7 MOD. L. REV. 97 (1944). 
to be the initial making and lasting bedrock of his academic career, it was also ironically to be the source of his limited appeal and stature in English and Commonwealth legal theory circles. With Hart's transforming revival of the analytical tradition, Stone's work was kept outside the jurisprudential mainstream.

In his path-breaking essay of 1944, Stone lamented the fact that "analytical jurisprudence is 'The Jurisprudence'." He demonstrated that, while conceptual illumination and logical clarification were not unpardonable ills, they must not be understood as valid jurisprudential ends in themselves: they must be deployed in the service of a fuller account of law's social operation and institutional role. For Stone, there was much more to law and its theoretical study than a dry and self-serving "logic chopping." Revealing his sociological leanings, he showed how Bentham and Austin's reformist efforts to discredit natural law thinking were "so effective ... that the theory of justice itself was stricken low and so far as English law teaching is concerned has not to this day fully recovered." Indeed, it was this tendency for "a dominant Austinianism ... to exclude all other inquiries" that most angered Stone. While he conceded that "the logical treatment of analytical jurisprudence is not 'fallacious' within its own proper universe of discourse," he insisted that such a narrow perspective must be supplemented by a jurisprudential approach which better connected, not further severed law from its social causes and consequences. ${ }^{14}$

For example, Stone took a robustly censorial stance towards Hart's work. Although Hart's refurbishment of Austin's command theory by way of elucidating how law was a system of primary and secondary rules was destined to take the jurisprudential world by storm and remain regnant for the second half of the Twentieth century, Stone thought very little of The Concept of Law. He considered its linguistic-based contribution to jurisprudential study to be "derivative or terminological or inconsequential". In particular, Stone could not view it as being the huge

This essay is incorporated in a slightly revised, if much expanded form in THE PROVINCE AND FUNCTION OF LAW: LAW AS LOGIC, JUSTICE AND SOCIAL CONTROL, A STUDY IN JURISPRUDENCE (1947).

14 Stone, The Province, id. at 98, 99, 102, 103 and 179. 
step forward in jurisprudential thinking that its champions proclaimed. He saw it as further narrowing inquiry and cutting off legal theory from more enriching and expansive versions and visions of what might be the best approach to useful jurisprudential endeavour. Barely managing to disguise his exasperation that such a rewarmed dish of legal positivism should marginalise his own more innovative work, he found Hart's claim that he was offering 'an essay in descriptive sociology' to be, at best, "a puzzle."15 Stone would be the first to applaud a shift in jurisprudential away from the claustrophobic concerns of analytical jurists towards a more expansive 'sociological' focus, but Hart's celebrated philosophical monograph was decidedly not the vehicle for achieving this.

In order to make a much more serious job of producing 'an essay in descriptive sociology', Stone set about offering his own theory of lawand-society jurisprudence. Like his mentor Pound, Stone took on board the bracing Realist critique of analytical jurisprudence, but he maintained that law and its study must be based on more solid footings than thoroughgoing scepticism and practical experience. For Pound and Stone, Realism was not an end in itself, but a means to a more informed and richer understanding of law's operations. Taking a more rigorous scientific approach over Realism's pragmatic leanings, he devoted himself to developing an expansive law-and-society approach to legal theory. Apart from taking saw sociology as a science which could provide invariant and validated facts about human nature and social relationships and thereby "deliver law-like generalities about law" so that "knowledge of the social process can be extended and that man's power over his own destiny can increase with that knowledge.”16

Yet, although quite radical in its day and influential even today, Stone's straddling of the Formalist-Realist divide left him vulnerable. In particular, his unwillingness to abandon entirely the search for a more

15 LEONIE STARR, JULIUS STONE: AN INTELLECTUAL LIFE 162 (1992). For a fascinating comparison of Stone and Hart's lives, see Michael Kirby, H.L.A. Hart, Julius Stone, and the Struggle for the Soul of Law, 27 SYDNEY L. REV. 323 (2005).

16 JULIUS STONE, SOCIAL DIMENSIONS OF LAW AND JUSTICE 391 and 783 (1966). 
compelling and foundationalist framework for understanding law placed him closer to the analytical tradition than he intended or desired. As part of his 'act of revolt' against the Austinian tradition of analytical jurisprudence, Stone only went so far as to insist that it be placed in "perspective" and its "limited nature" be appreciated. He was not prepared to announce that analytical jurisprudence had a pervasive negative influence and ought to be abandoned entirely. Throughout his career, he recognised that analytical jurisprudence has a place in the curriculum, "but its limited nature should be recognised." Alongside the analytical project, he demanded that a place must be found in the jurisprudence syllabus for Sociological (or Functional) Jurisprudence and for a jurisprudence of justice. Only once jurisprudence has been rearranged in accordance with what Stone terms "the AnalyticalSociological-Theory of Justice division" might it "escape from the present impasse, in which all branches of jurisprudence are treated as but ancillary to analytical jurisprudence.” As such, Stone concluded that it must no longer remain the case that a theory of justice is considered "beyond the proper scrutiny of the discreet lawyer, rather than as a necessary part of his equipment."17

Whether this recognition of analytical jurisprudence's continuing, if limited relevance was a matter of strategic academic manoeuvring (so that he would not be marginalised even more) or as a genuine intellectual acknowledgment is unclear. However, what is clear is that, for all its improvement upon the traditional literature of contemporary jurisprudence, Stone's own sociological alternative is closer in disciplinary spirit to the analytical project than he appreciated or cared to accept. Although he took a less internalised approach and nurtured a revived interest in the just dimensions of law, he still shared something of the scientistic and universalistic ambitions of the analytical project. Whereas many analytical jurists sought to ground law in its own internal structures and logic, Stone worked to offer a determinative account which drew upon the "elementary doctrine of the social sciences that law is conditioned by the social, political, and economic environment as well as by human

17 See PROVINCE AND FUNCTION, supra, note ** at vii, 31, 182, 192, 187 and 11. 


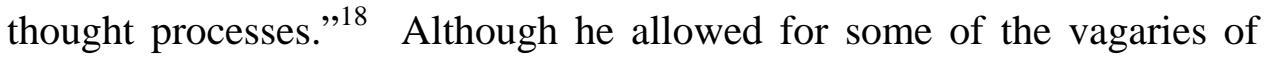
'human thought processes', his considerable oeuvre is clearly based on the belief that it is possible and desirable to make science-like claims about law's social character and function. He is in the Austinian business of seeking to deliver some of the secure truths and dependable knowledge that have so far eluded traditional analytical jurisprudence by developing "the science of jurisprudence (or, simply and briefly, jurisprudence)" by way of the social sciences. ${ }^{19}$

In delivering the 'essay in descriptive sociology' that Hart promised, but failed to deliver, Stone embraced the sociological method as a better way to explain the evolution of law and its adjudicative performance. In so doing, he placed faith in the capacity of a more empirical-based analysis to put some scientific backbone into the mushier techniques of traditional legal analysis and ensure that the policy-making practices of law would be better and more reliably informed. ${ }^{20}$ However, while scientific thinking can certainly add something to the jurisprudential project, it is folly to maintain that it can completely rule the field and become the master-method for obtaining knowledge about law which will replace all other techniques and vocabularies. Stone's scientific turn is less towards science than it is towards scientism. He manages to pull off the dubious feat of turning a series of relatively soft and loose intuitions about law in the late Twentieth Century into a pseudo-scientific theory of supposed hard facts about law and society generally. In short, although Stone claimed to stand on solid ground when he engages with law's facts, social interests and their relationship, the epistemological and ontological place where he stands and the facts that he analyses are much mushier and

Stone, SOCIAL DIMENSIONS, supra, note ** at 190.

19 JOHN AUSTIN, THE PROVINCE OF JURISPRUDENCE DETERMINED 7778 and 126 (1832: H.L.A. Hart ed. 1955).

20 Apart from Pound's own wide-ranging work, the effort to rely on the social sciences has a long pedigree and is currently experiencing something of a jurisprudential revival. See BRIAN LEITER, NATURALIZING JURISPRUDENCE: ESSAYS ON AMERICAN LEGAL REALISM AND NATURALISM IN LEGAL PHILOSOPHY (2007) and Thomas Miles and Cass Sunstein, The New Legal Realism, 75 U. CHI. L. REV. ** (2008). 
evaluative than he or other legal sociologists pretend. Although such sociological pursuits are illuminating, they are not foundational in the way that their exponents think. In a manner of speaking, when it comes to understanding law, it is relative mushiness (i.e., historical contexts, social values and political interests) all over the place and all the way down.

Accordingly, in redetermining the province of jurisprudence, I want to take a different tack to Stone. Rather than take a stand in the name of a 'law-and-society' sensibility, I will advance a critique in line with a more thoroughly pragmatic approach to law and legal theory. Stone pointed us in the right direction in his apparent rejection of analytical jurisprudence, but he stopped short in travelling down that path to its suggested destination. If he had taken a few steps further along this antianalytical path, he might have moved beyond its debilitating influence. As it was, he remained within the intellectual force-field of analytical philosophy. Although he was committed to shaking off the limited and limiting role of analytical jurisprudence, Stone remained within the ample embrace of its underlying philosophical tradition in which epistemology and truth continued to hold sway as the ruling standards. In moving from legal theory to law-and-society theory, he shifted from the study into the street, but he still retained much the same mind-set when he excavated and explored law' social interests and dynamics. Stone was still in the business of not only looking to ground the jurisprudential in something outside itself and outside history, but also establishing the enduring and scientific status of such connections. In contrast, I maintain that the best way to challenge analytical jurisprudence is to forego any lingering attachment to such traditional shibboleths as truth, objectivity and universality in offering conceptual certainties or sociological insights. I suggest a pragmatic and democratic jurisprudential account that measures the worth of legal theory less by the lights of abstract philosophical speculation and more by the demands of useful political knowledge.

\section{A DEMOCRATIC TURN}

Analytical jurists have made considerable contributions to the understanding of law as a privileged mode of social ordering. However, it is their foundational claim that a strictly philosophical and conceptual 
approach to law is the primary and best jurisprudential method by which to proceed that offends. The assertion of disciplinary authority over rival approaches is the full measure of their wrongdoing. This analytical focus has done much more harm than good: its presumptive refinement and clarity has been outweighed by its revealed narrowness and abstraction. Masquerading as a general and detached pursuit that can be relevant to all legal systems in all places at all times, analytical jurisprudence has a definite history and is part of a contested political tradition. Indeed, for all its claims to rigour and exactness, this philosophical tendency has much softer and more contingent foundations than is supposed or claimed: it is not the hard and detached discipline that its proponents recommend it to be. As a political tradition as much as an intellectual tendency, analytical jurisprudence deserves to be assessed in terms of its political orientation generally and its democratic compatibility particularly.

Democracy is the commitment par excellence to the idea that almost all choices and actions have political roots and political consequences: people can tackle those politics within a framework within which their active participation is more important than (or, at least, as important as) that of elected representatives, political sages or judicial officials. In contrast to its present weak and anaemic practice, therefore, strong democracy has a broad mandate (i.e., including social and economic as well as political matters) and deep mandate (i.e., requiring regular and sustained acts of participation) which combine to ensure that people become full and active citizens. Members of society are neither subjects nor subservients, but 'citizens' in the fullest sense of that term; they should be empowered to participate in all aspects of the political, social and intellectual life of the community. ${ }^{21}$

In developing a democratic jurisprudence, therefore, it will be important to ensure that jurists do not become part of another ruling elite. Democracy is opposed to all efforts to accumulate and exercise power by the few over the many; it seeks to exert a centrifugal rather than centripetal influence on power. This democratic admonition against elite control is

21 For fuller development of 'strong democracy', see ALLAN C. HUTCHINSON, THE COMPANIES WE KEEP: CORPORATE GOVERNANCE FOR A DEMOCRATIC AGE (2006). 
particularly pertinent in regard to analytical jurisprudence. Claiming to speak in the name of universal truths and under the authority of abstract authority, analytical jurists represent a subtle, yet substantial threat to the democratic project. As a philosophical enterprise, analytical jurisprudence commits itself to the idea that a successful theory of law must locate those essential properties of law which are both necessarily true and are adequate to distinguish it from other modes of social control: it must "tell us truths which illuminate that which is most important about and characteristic of law."22 Indeed, much of contemporary jurisprudence has become largely epistemological in that a central concern is with determining the truth-conditions for knowledge about law. Although there are recent indications of a less hubristic stance, there remains a certain confidence that the traditional analytical tools -- theoretical argumentation, objective evidence, conceptual clarity, systemic coherence, ahistorical orientation, etc. -- are up to the task of laying solid epistemological foundations for the essentialist project of analytical jurisprudence. This is an elitist enterprise of the first order. By holding out the alluring prospect of objective knowledge about law's practices, analytical jurists exhibit a lack of confidence in their fellow citizens and set themselves up as philosophical experts who not only know something better about law, but also know something better about 'knowing'.

In contrast, the strong democrat insists that there is no philosophical authority that can claim priority over a democratic community of good-willed participants coming together and deciding what is the most useful thing to do in difficult circumstances: "there's no God, no reality, no nothing that takes precedence over the consensus of a free people -- there's no court of appeal higher than a democratic consensus."23 In allowing for the epistemological possibility that there is an analytical

22

JULIE DICKSON, EVALUATION AND LEGAL THEORY 25 (2001).

23 A Conversation with Richard Rorty, ATLANTIC UNBOUND, April $23^{\text {rd }} 1998$. RICHARD RORTY, PHILOSOPHY AND THE MIRROR OF NATURE 181 (1979). See also RICHARD RORTY, CONSEQUENCES OF PRAGMATISM (1982) and RICHARD RORTY, CONTINGENCY, IRONY, SOLIDARITY (1989). While strongly influenced by Richard Rorty's writings, I re-work his pragmatism in line with a stronger commitment to democratic politics. See ALLAN C. HUTCHINSON, THE PROVINCE OF JURISPRUDENCE DEMOCRATISED (2008). 
method for 'illuminating truths' which is separate from a democratic society's own efforts to act justly and fairly and which can underwrite those efforts, analytical jurists betray the democratic spirit of inquiry, debate, and action. To differing degrees, analytical jurists set themselves up as comprising an illegitimate court of appeal and claim expert status in determining knowledge about the reality of law's truth. This can be true whether such jurists look to conceptual analysis or social science as their guiding standard.

Strong democrats resist such analytical claims. Locating knowledge and truth within a communal set of practices and engagements, they evince an implacable opposition to epistemological methodology generally: they want to engineer a shift from philosophical reflection to political engagement. This involves a relentless insistence that there are no bright-line boundaries or essential methodological differences between theory and practice, natural and social science, facts and values, philosophy and conversation, and, of course, law and politics. It is not that these categorical distinctions are thought to collapse in on each other and have no relevant differences at all, but that such differences are contingent and social because they always arise from and within, directly or indirectly, their sustaining historical and political context. Like law itself, legal theory is seen to be thoroughly political in scope and substance. As such, a thoroughgoing democratic approach maintains that there is no possibility of a purely descriptive jurisprudence insofar as that entails resort to any kind of epistemological device that strives to ascend to a higher ahistorical ground from which to deliver truths, conceptual or social, about law's identity or the essential qualities of other social practices. While experience has taught that some techniques or resources are better suited to produce reliable results in some fields than others, there is no detached or definitive vantage-point from which to determine which technique or resource is objectively suited to one task or another. There are only needed those arguments and reasons which have passed social muster in an open and intelligent exchange. Moreover, because these social conversations and philosophical conventions are themselves open to the changing and dynamic forces of historical contestation, they are at least vulnerable to and often affected by political and social values.

Rather than appreciate it as a self-contained philosophical pursuit, analytical jurisprudence can be more usefully apprehended as part of a 
continuing political tradition which privileges certain values and interests over others. $^{24}$ Once understood as an engaged political intervention, analytical jurisprudence can be evaluated in terms of its compatibility with the demands and standards of a democratic approach. As with almost all other social practices, the disciplinary strictures of analytical jurisprudence will be shown not to be immune from the push-and-pull of various social, economic, institutional, ideological and cultural currents. Because objectivity is about compliance with those accepted and agreed-upon standards for justifying knowledge, it will be crucial to ascertain and examine the terms and conditions under which such social agreements are reached and enforced. Of course, it ought to come as no surprise that such understandings and arrangements are themselves subject to the contingent play of various practical forces and professional interests. Consequently, what has managed to get itself accepted in the relevant community of scholarly study will be attributable to more than (or, perhaps, less than) the raw force of a 'good idea'. As Stone glimpsed, but did not fully act upon, the virtues of factual or epistemic values are not as apparent or insulated from political values as their proponents would recommend: they are similarly, if not equally connected to the social matrix of forces that gestate and perpetuate them.

A more suitable characterisation of the jurist's function is to be found in the exhortation to worry less about flying higher or digging deeper to ascertain truth and knowledge about law which has enduring validity beyond society's own situation and challenges. Instead, jurists who are prepared to follow through unconditionally on the democratic imperative look to explore and broaden the ways in which a society's conversations about law can be made more useful to its members. This involves the acceptance that there are no conversation-ending or truthfixing arguments other than those that gain acceptance in engaged debate and open inquiry in particular historical circumstances. Consequently, democratic jurists will eschew the analytical tendency to take such matters entirely out of the hands of citizens and to reserve them as only for those with philosophical or jurisprudential competence. The more modest role of jurists is to use their technical skill and institutional experience to

24 See David Dyzenhaus, The Genealogy of Legal Positivism, 24 OXF J. OF LEGAL STUDIES 39 at 40 (2004). 
facilitate and contribute to democratic debate, not usurp it in the name of philosophical authority. In meeting such a task, the effort to determine and defend insights about law in terms of their universal merit or enduring appeal is simply a distraction. Rather than take an almost perverse pride in the unworldliness of their views, democratic jurists will recognise that treating their work as 'local enthusiasms' is a useful compliment, not a dismissive criticism.

There is nothing about this defence of a robustly democratic society which depends on any philosophical claim or epistemological back-up that such a society is more natural, more rational, more coherent, more pure or more anything else than any other society. And it is certainly not that it more closely approximates to some established notion of Truth. On the contrary, it is simply a practical argument that such a society is more useful in a world in which there are no philosophically-mandated truths and in which people must be allowed to experiment for themselves with how they might best be organised and live their lives. Democracy's appeal is that it establishes its own 'foundations' and 'authority' by making them the property of the community and by ensuring that they are always open to critical transformation. Because it is deliberative rather than programmatic, strong democracy reinforces and comes closest to actualising a social and institutional practice which keeps faith with the key pragmatic claim that there is no basis in ethics, epistemology or politics, to rely on any source of authority other than that which arises in and from social practices. Even if critics cannot speak in the name of Reason or Humanity, they need not celebrate the status quo or some reformist understanding of it. The justice of any situation might be measured by the extent and depth of people's participation in the formulation and re-formulation of the terms and conditions of their own lives. In this way, people might become genuine citizens and resist the expedient temptation to mistake the contingent nostrums of analytical philosophers for enduring truths about social arrangements and the human condition. The status quo is owed no greater (or lesser) respect than any other set of institutional ordering; it is a place from which to begin and experiment. 


\section{CONCLUSION}

Looking back over the past couple of decades, Stone would likely be both troubled and reassured. His plea for a more expansive and socially-informed understanding of jurisprudence and its legitimate province has been only partially heeded. While there is more variety of approaches and a real sense that justice is worth talking about, analytical jurisprudence, especially in its dominant positivistic mode, remains the leading jurisprudential approach around which others must orient themselves. If Stone's mission to redetermine the province of jurisprudence is to be accomplished, then it will not be sufficient to abandon analytical jurisprudence. As long as analytical jurisprudence remains even part of the lawyer's intellectual project, then considerations of substantive justice will be, as Stone put it, ' beyond the proper scrutiny of the discreet lawyer' and not 'a necessary part' of the lawyer's basic tool-kit. Instead, it will also be necessary to effect a complete shift away a technical and elite philosophical-scientific approach to a more democratic jurisprudential engagement. Like the law it seeks to illuminate, legal theory must recognise its own political and social setting as well as its own responsibilities. Moreover, law's operation is organic, messy and purposive -- any legal theory that fails to appreciate and incorporate that in its analysis and in its analytical method is destined to fail as a valid, useful and/or democratic jurisprudence. Unlike the detached, static, abstract and precious quality of much Austinian-inspired analytical jurisprudence, a democratic jurisprudence can be engaged, vibrant, accessible and political. 